\title{
Hypothermic Cardiopulmonary Bypass: A Comparison between Alpha and pH Stat Regulation in the Dog
}

\author{
Edward L. Bove, M.D.,' Howard L. West, B.S., AND ANDrew M. PaSKaniK \\ Departments of Surgery, State University of New York Upstate Medical Center, Syracuse, New York; \\ and The University of Michigan Medical Center, Ann Arbor, Michigan
}

Submitted for publication November 6, 1985

\begin{abstract}
The accepted normal $\mathrm{pH}$ of 7.40 may not be optimal at lower temperatures. This study evaluated the effect of maintaining $\mathrm{pH}$ in the accepted normal range at hypothermia (group 1, pH stat) or at normothermia (group 2, alpha stat) on organ blood flow and hemodynamics in dogs. The desired $\mathrm{pH}$ was achieved at all temperatures by adjusting $\mathrm{pCO}_{2}$. Hypothermia to $20^{\circ} \mathrm{C}$ was induced by high flow bypass in both groups followed by $45 \mathrm{~min}$ of reduced flow before rewarming. In group $1(n=10)$, pH was 7.45 \pm 0.02 at $20^{\circ} \mathrm{C}$ and in group $2(n=11)$ it was $7.64 \pm 0.01$. A greater base excess developed by the end of the low flow period in $\mathrm{pH}$ stat animals $(-9.4 \pm 1.1 \mathrm{vs}-2.8 \pm 0.8, P<.001)$ and resulted in continued acidosis after rewarming in the $\mathrm{pH}$ stat group compared to those in the alpha stat group $(7.32 \pm 0.03$ vs $7.38 \pm 0.01, P<.02$ ). Expressed as a percentage of baseline, regional blood flows after rewarming for group 1 were: brain $112 \pm 8 \%$, renal cortex $48 \pm 8 \%$ ( $P<0.005$, rewarm vs basclinc), renal medulla 36 $\pm 9 \%(P<0.005$, rewarm vs baseline), epicardium $198 \pm 40 \%(P<0.05$, rewarm vs baseline), endocardium $151 \pm 25 \%$. The values for group 2 were: brain $108 \pm 11 \%$, renal cortex $59 \pm 8 \%(P<0.005$, rewarm vs baseline), renal medulla $63 \pm 15 \%$, epicardium $158 \pm 18 \%(P<0.005$, rewarm vs baseline), endocardium $129 \pm 10 \%$ ( $P<0.025$, rewarm vs baseline). There were no significant differences between groups 1 and 2. Relative to baseline, there were no differences in cardiac output, mean systemic pressure or mean pulmonary artery pressure between the two groups. This study indicates that alterations in $\mathrm{pH}$ and $\mu \mathrm{CO}_{2}$ control between alpha and $\mathrm{pH}$ stat regulation assume lesser importance for regional blood flow when normal systemic flow is maintained during cooling and rewarming. (c) 1987 Academic Press, Inc.
\end{abstract}

\section{INTRODUCTION}

The optimal $\mathrm{pH}$ for patients undergoing cardiac surgery using deep hypothermia has not been determined. The accepted normal value for $\operatorname{man}(\mathrm{pH}=7.40 \pm 0.05)$ is measured at a blood temperature of $37^{\circ} \mathrm{C}$ and may not be appropriate as body temperature is lowered $[13,20,21]$. Ample evidence exists in ectothermic animals that $\mathrm{pH}$ increases as body temperature falls in order to maintain $\mathrm{CO}_{2}$ stores constant $[13,20]$. This pattern of hydrogen ion control, referred to as alpha stat regulation, is achieved in ectotherms by maintaining a "normal" minute ventilation (for $37^{\circ} \mathrm{C}$ ) resulting in relative hypocarbia and alkalosis as body temperature falls [13]. In contrast, hibernating animals reduce minute

\footnotetext{
${ }^{1}$ To whom reprint requests should be addressed: Taubman Center, 1500 East Medical Center Drive, $2120 \mathrm{~F}$, Box 0344, Ann Arbor, Mich. 48109.
}

ventilation in an effort to maintain the same normothermic $\mathrm{pH}$ and $p \mathrm{CO}_{2}$ values at lower temperatures. This pattern, $\mathrm{pH}$ stat regulation, results in a relative respiratory acidosis when measured at normothermia [13].

When hypothermia is induced for cardiac surgery in infants, preliminary surface cooling may be used. Ventilation is therefore controlled by the anesthesiologist while each organ cools in proportion to the cardiac output and regional blood flow. Some groups utilize deliberate hypoventilation ( $\mathrm{pH}$ stat), believing that the elevated $p \mathrm{CO}_{2}$ increases cerebral blood flow. Others feel that normal ventilation results in improved cardiac output and that this is more important for individual organ flow. However, many surgical groups now induce hypothermia without initial surface cooling, lowering body temperature solely on cardiopulmonary bypass. Ventilation then becomes unnecessary and the $\mathrm{pH}$ and $p \mathrm{CO}_{2}$ must by 
controlled through the pump oxygenator. The importance of $\mathrm{pH}$ and $p \mathrm{CO}_{2}$ regulation in this setting has not been previously assessed.

This study compares these two methods of $\mathrm{pH}$ control in dogs subjected to deep hypothermia on cardiopulmonary bypass. Cooling was induced entirely with high flow bypass as is commonly done clinically. In this way, the influence of $\mathrm{pH}$ and $p \mathrm{CO}_{2}$ on individual organ flows and hemodynamics when total body flow was held constant during cooling and rewarming could be assessed.

\section{METHODS}

Adult mongrel dogs weighing 18 to $26 \mathrm{~kg}$ were anesthetized with intravenous sodium pentobarbital and ventilated with room air using a volume cycled Harvard respirator. All animals received humane care in compliance with the "Principles of Laboratory Animal Care" formulated by the National Society for Medical Research and the "Guide for the Care and Use of Laboratory Animals" prepared by the National Academy of Sciences and published by the National Institutes of Health (NIH Publication 80-23, revised 1978). Tidal volume and rate were initially adjusted to maintain $p \mathrm{CO}_{2}$ between 30 and 35 Torr and pII between 7.35 and 7.45. Lactated Ringer's solution was given intravenously $(20 \mathrm{ml} / \mathrm{kg})$. The femoral artery was cannulated for arterial pressure and a thermodilution Swan-Ganz catheter was placed via the right internal jugular vein. A temperature probe was inserted into the rectum.

A median sternotomy was performed and the pericardium opened. A cannula was inserted into the left atrial appendage for pressure monitoring and microsphere injection. Baseline data consisting of cardiac output (thermodilution), systemic blood pressure, pulmonary artery pressure, central venous and left atrial pressure, hematocrit, $\mathrm{pH}, p \mathrm{O}_{2}$, $p \mathrm{CO}_{2}$, and base excess were obtained. Heparin, $300 \mathrm{IU} / \mathrm{kg}$, was administered intravenously. Cardiopulmonary bypass was instituted using separate superior and inferior vena cava cannulas. The ascending aorta was cannulated for arterial return. A vent was placed through the apex of the left ventricle and the cavas were snared. Standard non-pulsatile flow at $100 \mathrm{cc} /$ $\mathrm{kg} / \mathrm{min}$ was instituted with a Cobe-Stockert pump and Cobe membrane oxygenator (Cobe Laboratories, Inc., Lakewood, Colo.). Rectal temperature was gradually reduced to $20^{\circ} \mathrm{C}$ using an in-line heat exchanger.

At $20^{\circ} \mathrm{C}$, flow was reduced to $25 \mathrm{ml} / \mathrm{kg} /$ $\mathrm{min}$ for $45 \mathrm{~min}$, followed by high flow $(100$ $\mathrm{ml} / \mathrm{kg} / \mathrm{min}$ ) rewarming. When rectal temperature again reached $37^{\circ} \mathrm{C}$, the animals were weaned from cardiopulmonary bypass and allowed to stabilize for $20 \mathrm{~min}$. The same respiratory rate and tidal volume used for baseline measurements were maintained. No inotropic agents were administered. Volume from the pump was transfused to achieve baseline central venous and left atrial pressures. Hematocrit was kept constant by adding blood to the pump as needed. All pressure measurements, cardiac output and arterial blood gases were repeated. The animals were then sacrificed for blood flow measurements.

Microsphere injections and measurement of organ flow. Organ blood flows were measured by injecting $15 \pm 3 \mu \mathrm{m}$ microspheres suspended in $10 \%$ Dextran with $0.01 \%$ Tween 80 labeled with ${ }^{141} \mathrm{Ce},{ }^{85} \mathrm{Sr}$ or ${ }^{51} \mathrm{Cr}$ (3M Co., Minneapolis, Minn.). Thermodilution cardiac output was measured immediately before microsphere injection. In 5 animals, cardiac output was also determined by simultaneously withdrawing a reference sample of $4 \mathrm{ml}$ over $1 \mathrm{~min}$ from the femoral artery. These values correlated closely with those from thermodilution. Microspheres were injected at three intervals: (1) immediately following measurement of baseline hemodynamics before cardiopulmonary bypass, (2) at the completion of core cooling before instituting low flow, and (3) 20 min after weaning from cardiopulmonary bypass following repeat hemodynamic measurements. The order of microsphere injections was varied between experiments. The spheres were injected via the left atrial line for the first and third injections and in a side arm off the aortic perfusion cannula for the second measurement. The number of spheres injected 
was precalculated to deliver $1 \times 10^{6}$ spheres per injection. Regional flows were obtained from the brain, kidney, and heart. Brain samples were taken from four areas: tip of the frontal lobe, watershed area between the anterior and middle cerebral artery distributions, caudate nucleus, and tip of the occiptal lobe. Kidney samples were cut to separate the cortex and medulla after removing the outer capsule and collecting tubules. Heart samples were taken from the left ventricular free wall, away from papillary muscles. Slices were divided into an inner (endocardium) and outer (epicardium) half. All samples were dried, weighed, and placed into counting vials. Triplicate samples were taken for each measurement and the results averaged. Counts were determined for each window setting on an LKB Gamma counter. Tissue blood flow, expressed as milliliters per minute per gram of tissue, was calculated according to the formula: organ flow $(\mathrm{ml} / \mathrm{min} / \mathrm{g})=\%$ dose $\times$ cardiac output [6].

Regulation of $p H$. The animals were divided into two groups. In group $1(n=10)$, arterial $\mathrm{pH}$ was kept at $7.40 \pm 0.05$ at the dog's actual temperature (pH stat). In group $2(n=11)$, $\mathrm{pH}$ was kept at $7.40 \pm 0.05$ as measured at $37^{\circ} \mathrm{C}$ regardless of the dog's temperature at the time of measurement (alpha stat). The desired $\mathrm{pH}$ was achieved by adjusting the arterial $p \mathrm{CO}_{2}$ through the gas flow in the pump oxygenator. During both cooling and rewarming, $p \mathrm{CO}_{2}$ was adjusted so that the $\mathrm{pH}$ changes would reasonably follow the Rosenthal equation: $\Delta \mathrm{pH} /{ }^{\circ} \mathrm{C}=0.015[16,20]$. For each measurement, blood gases were measured both at electrode temperatures of $37^{\circ} \mathrm{C}$ and at the blood temperature at the time of the measurement, rather than simply using the Rosenthal equation to correct for temperature. No sodium bicarbonate was administered once cooling was begun. $\mathrm{pH}$ and $p \mathrm{CO}_{2}$ were measured at $37,32,27$, and $20^{\circ} \mathrm{C}$ during the cooling and rewarming phases to achieve the proper value at each temperature.

Statistical analysis. Statistical significance was determined at the $95 \%$ confidence level using Student's $t$ test and paired $t$ test. Values are expressed as mean \pm standard error. Ratios and percentages were derived from individual animals and then expressed as a mean.

\section{RESULTS}

\section{pH Control}

The arterial $\mathrm{pH}$ for both groups was kept close to the confines of the equation $\Delta \mathrm{pH} /{ }^{\circ} \mathrm{C}$ $=0.015$ at each of the four temperatures at which it was measured. The values for $\mathrm{pH}$, $p \mathrm{CO}_{2}$ and base excess for both groups are shown in Table 1. Control values for $\mathrm{pH}$ were the same in both groups. After the completion of core cooling in group 1 animals, $\mathrm{pH}$ was $7.45 \pm 0.02$ as measured at $20^{\circ} \mathrm{C}$ (Fig. 1). This value was $7.21 \pm 0.02$ when the blood samples were repeated at $37^{\circ} \mathrm{C}$ (Fig. 2). For group 2, $\mathrm{pH}$ was $7.64 \pm 0.01$ at $20^{\circ} \mathrm{C}$ and $7.40 \pm 0.01$ at $37^{\circ} \mathrm{C}(P<.01$, group 1 vs group 2$)$. After discontinuing cardiopulmonary bypass, $\mathrm{pH}$ remained significantly higher in the alpha stat group. The control values for arterial $p \mathrm{CO}_{2}$ were also the same for both groups. At $20^{\circ} \mathrm{C}$, $p \mathrm{CO}_{2}$ was significantly higher in group 2 ( $P$ $<0.01$ ). After rewarming, $p \mathrm{CO}_{2}$ values were not different between alpha $(38 \pm 1.4)$ and $\mathrm{pH}$ stat (42 \pm 2.1$)$ animals, $P=\mathrm{NS}$.

Control values for base excess were not different between groups. After the end of the 45

TABLE 1

ARTERIAL BLOOD Gases ACTUAL TEMPERATURE VALUES

\begin{tabular}{lccc}
\hline & $37^{\circ} \mathrm{C}$ & $20^{\circ} \mathrm{C}$ & $37^{\circ} \mathrm{C}$ \\
& Control & End low flow & Off bypass \\
\hline Alpha stat & & & \\
pH & $7.42 \pm 0.01$ & $7.64 \pm 0.01^{*}$ & $7.38 \pm 0.01 \ddagger$ \\
pCO & $32 \pm 0.9$ & $15 \pm 0.7^{* *}$ & $38 \pm 1.4$ \\
Base excess & $-3.2 \pm 0.6$ & $-2.8 \pm 0.8^{* * *}$ & $-2.3 \pm 0.7 \dagger$ \\
pH stat & & & \\
pH & $7.43 \pm 0.01$ & $7.45 \pm 0.02^{*}$ & $7.32 \pm 0.03 \ddagger$ \\
$p \mathrm{CO}_{2}$ & $31 \pm 1.4$ & $23 \pm 1.0^{* *}$ & $42 \pm 2.1$ \\
Base excess & $-3.9 \pm 0.8$ & $-9.4 \pm 1.1^{* * *}$ & $-5.0 \pm 0.8 \dagger$ \\
\hline
\end{tabular}

$$
\begin{aligned}
& * P<0.1 \text {. } \\
& \text { ** } P<0.01 \text {. } \\
& \text { **** } P<0.001 \text {. } \\
& \dagger P<0.05 \text {. } \\
& \ddagger P<0.02 \text {. }
\end{aligned}
$$


ARTERIAL PH AT ACTUAL TEMPERATURE

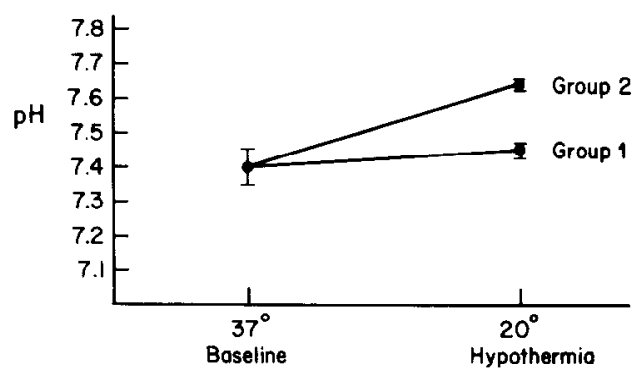

FIG. 1. Arterial $\mathrm{pH}$ at actual temperature.

min low flow period, the base excess for the alpha stat group was unchanged. This was significantly better than that found in the $\mathrm{pH}$ stat group. This difference persisted after rewarming. Twenty minutes after discontinuing cardiopulmonary bypass with all animals restored to baseline levels of ventilation, the base excess for $\mathrm{pH}$ stat animals was significantly greater than that for the alpha stat group. This difference in base excess explains the lower $\mathrm{pH}$ in the $\mathrm{pH}$ stat group after rewarming.

\section{Hemodynamic Measurements}

Baseline cardiac output was $2.64 \pm 0.29$ liter/min for group 1 and $2.82 \pm 0.24$ liter/ min for group 2 . After rewarming and discontinuing cardiopulmonary bypass cardiac output was restored to $84 \pm 11 \%$ of control in group 1 and to $84 \pm 9 \%$ in group 2 (NS).

The baseline mean femoral artery blood pressure for group 1 was $89 \pm 5.0 \mathrm{~mm} \mathrm{Hg}$ and was $101 \pm 5.4 \mathrm{~mm} \mathrm{Hg}$ for group 2. The rewarm mean femoral artery pressure was 63 $\pm 6 \%$ of baseline for group 1 and $62 \pm 5 \%$ for group 2 (NS). There were no significant changes in mean pulmonary artery pressure, left atrial pressure or central venous pressure between baseline and rewarming for either group.

\section{Organ Blood Flow}

Brain. Mean blood flows to each of the four areas of the brain are listed in Table 2. Regional flows decreased markedly during hypothermia for both groups. When all four areas were taken as a whole, group 1 flow was 65 $\pm 11 \%$ of baseline $(P<0.005)$ and group 2 was $45 \pm 6 \%(P<0.005)$. There was no difference between groups. Rewarm flow was not significantly different from baseline in either group. For all four areas taken as a whole, group 1 rewarm flow was $113 \pm 17 \%$ of baseline and group 2 was $109 \pm 8 \%$.

Kidney. Mean blood flows to the renal cortex and medulla are shown in Table 3. Hypothermia flows for the cortex were markedly reduced. In group 1, hypothermic flow was 19 $\pm 3 \%$ of baseline and for group 2 it was 21 $\pm 4 \%$. Hypothermic flow for the renal medulla was $66 \pm 28 \%$ of control and $100 \pm 56 \%$ of control for groups 1 and 2, respectively (NS, group 1 vs group 2).

Rewarm blood flow failed to reach baseline levels for the renal cortex. This ratio was 48 $\pm 8 \%$ for group 1 and $59 \pm 8 \%$ for group 2 . The difference between groups was not significant. For the renal medulla, rewarm to baseline was $36 \pm 9 \%$ for group 1 and $63 \pm 15 \%$ for group 2 ( $P=\mathrm{NS}$, group 1 vs group 2 ).

Heart. Table 4 lists the mean blood flows for the epicardium and endocardium of the heart. During hypothermia, epicardial flow was reduced to $43 \pm 16 \%$ of baseline for group 1 and $97 \pm 36 \%$ for group 2 . Endocardial flow was $40 \pm 14 \%$ for group 1 and $64 \pm 23 \%$ for group 2. Again, there was no difference between groups 1 and 2.

After rewarming, epicardial flow for group 1 was $198 \pm 40 \%$ of baseline and was 158 $\pm 18 \%$ for group 2 . The difference between group 1 and 2 was not significant. Endocardial

ARTERIAL $\mathrm{pH}$ of $37^{\circ} \mathrm{C}$ ELECTRODE TEMPERATURE

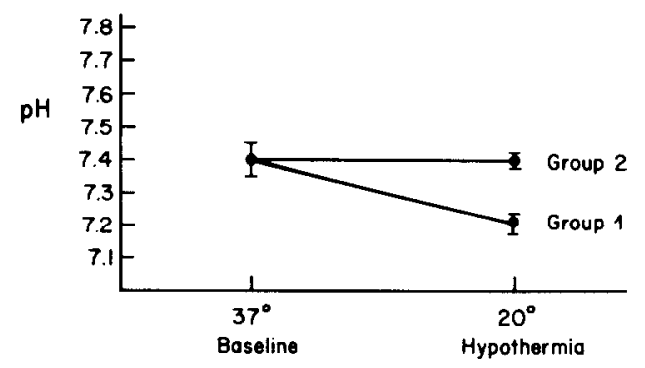

FIG. 2. Arterial pH at $37^{\circ} \mathrm{C}$ electrode temperature. 
TABLE 2

BraIN FLOW (ml/min/g)

\begin{tabular}{|c|c|c|c|c|c|c|c|c|c|c|}
\hline \multirow[b]{2}{*}{ Region } & \multicolumn{2}{|c|}{ Baseline } & \multicolumn{2}{|c|}{ Hypothermia } & \multicolumn{2}{|c|}{$P$ value $a$} & \multicolumn{2}{|c|}{ Rewarm } & \multicolumn{2}{|c|}{$P$ value ${ }^{b}$} \\
\hline & $\begin{array}{c}\text { Group } \\
1\end{array}$ & $\begin{array}{c}\text { Group } \\
2\end{array}$ & $\begin{array}{c}\text { Group } \\
1\end{array}$ & $\begin{array}{c}\text { Group } \\
2\end{array}$ & $\begin{array}{c}\text { Group } \\
1\end{array}$ & $\begin{array}{c}\text { Group } \\
2\end{array}$ & $\begin{array}{c}\text { Group } \\
1\end{array}$ & $\begin{array}{c}\text { Group } \\
2\end{array}$ & $\begin{array}{c}\text { Group } \\
1\end{array}$ & $\begin{array}{c}\text { Group } \\
2\end{array}$ \\
\hline Occipital & $0.81 \pm 0.12$ & $0.55 \pm 0.06$ & $0.39 \pm 0.08$ & $0.24 \pm 0.07$ & 0.025 & 0.005 & $0.80 \pm 0.13$ & $0.48 \pm 0.07$ & NS & NS \\
\hline Watershed & $0.72 \pm 0.12$ & $0.43 \pm 0.07$ & $0.55 \pm 0.25$ & $0.20 \pm 0.04$ & NS & 0.005 & $0.73 \pm 0.12$ & $0.45 \pm 0.05$ & NS & NS \\
\hline Frontal & $0.73 \pm 0.12$ & $0.53 \pm 0.07$ & $0.39 \pm 0.09$ & $0.23 \pm 0.04$ & 0.025 & 0.005 & $0.79 \pm 0.14$ & $0.52 \pm 0.07$ & NS & NS \\
\hline Caudate & $0.98 \pm 0.15$ & $0.71 \pm 0.11$ & $0.30 \pm 0.08$ & $0.15 \pm 0.04$ & 0.005 & 0.005 & $1.07 \pm 0.22$ & $0.68 \pm 0.09$ & NS & NS \\
\hline
\end{tabular}

${ }^{a}$ Baseline vs hypothermia.

${ }^{b}$ Baseline vs rewarm.

flow was $151 \pm 25 \%$ of control for group 1 and $129 \pm 10 \%$ for group $2(P=\mathrm{NS})$.

\section{DISCUSSION}

The ideal $\mathrm{pH}$ during deep hypothermia remains controversial $[10,13,14,17,20,21]$. Repair of complex cardiac malformations in infants and children usually involves profound hypothermia and low flow cardiopulmonary bypass or complete circulatory arrest. The regulation of arterial $\mathrm{pH}$ during these procedures is accomplished by one of two commonly used methods $[13,20]$. One method considers the "ideal" $\mathrm{pH}$ of 7.40 to be optimal at all temperatures ( $\mathrm{pH}$ stat regulation). Since the relationship between $\mathrm{pH}$ and temperature remains constant according to the Rosenthal equation: $\Delta \mathrm{pH} /{ }^{\circ} \mathrm{C}=0.015[3,5]$, a $\mathrm{pH}$ of 7.40 at $20^{\circ} \mathrm{C}$ would represent a significant acidosis when measured at $37^{\circ} \mathrm{C}(\mathrm{pH}=7.145)$. The second method follows the pattern of ectothermic animals. Thus, a $\mathrm{pH}$ of 7.40 is felt to be optimal only at $37^{\circ} \mathrm{C}$ and should increase inversely with temperature in order to maintain constant $\mathrm{CO}_{2}$ stores [13, 14]. A relative alkalosis during hypothermia results. Since, in the clinical setting, arterial blood gas measurements are made with electrodes calibrated for $37^{\circ} \mathrm{C}$ samples, the result must be "corrected" to the patient's actual temperature using the Rosenthal relationship [21]. Those groups practicing $\mathrm{pH}$ stat regulation decrease minute ventilation or add $\mathrm{CO}_{2}$ to the gas mixture in order to achieve the desired degree of respiratory acidosis. For those utilizing alpha stat regulation, minute ventilation must be maintained at euthermic normal values to obtain a relative alkalosis as the temperature is lowered. Practically speaking, as long as the blood gas values at $37^{\circ} \mathrm{C}$ are "normal," the proper $\mathrm{pH}$ and $\mathrm{pCO}_{2}$ for the decrease in temperature has been achieved.

A number of studies have examined the relationship between hypothermia and regional blood flow $[3-5,9,11,18,19,22]$. In a study

TABLE 3

KIDNEY FLOW (ml/min/g)

\begin{tabular}{|c|c|c|c|c|c|c|c|c|c|c|}
\hline \multirow[b]{2}{*}{ Region } & \multicolumn{2}{|c|}{ Baseline } & \multicolumn{2}{|c|}{ Hypothermia } & \multicolumn{2}{|c|}{$P$ value $^{a}$} & \multicolumn{2}{|c|}{ Rewarm } & \multicolumn{2}{|c|}{$P$ value ${ }^{b}$} \\
\hline & Group 1 & Group 2 & Group 1 & Group 2 & Group 1 & Group 2 & Group 1 & Group 2 & Group 1 & Group 2 \\
\hline Cortex & $8.90 \pm 0.82$ & $6.97 \pm 0.72$ & $1.63 \pm 0.23$ & $1.45 \pm 0.24$ & 0.005 & 0.005 & $4.29 \pm 0.80$ & $4.16 \pm 0.82$ & 0.005 & 0.005 \\
\hline Medulla & $0.06 \pm 0.01$ & $0.19 \pm 0.12$ & $0.02 \pm 0.04$ & $0.05 \pm 0.02$ & 0.005 & NS & $0.02 \pm 0.002$ & $0.10 \pm 0.06$ & 0.005 & NS \\
\hline
\end{tabular}

${ }^{a}$ Baseline vs hypothermia.

${ }^{b}$ Baseline vs rewarm. 
TABLE 4

HEART FLOW (ml/min/g)

\begin{tabular}{|c|c|c|c|c|c|c|c|c|c|c|}
\hline \multirow[b]{3}{*}{ Region } & \multicolumn{2}{|c|}{ Baseline } & \multicolumn{2}{|c|}{ Hypothermia } & \multicolumn{2}{|c|}{$P$ value ${ }^{a}$} & \multicolumn{2}{|c|}{ Rewarm } & \multicolumn{2}{|c|}{$P$ value ${ }^{b}$} \\
\hline & Group & Group & Group & Group & Group & Group & Group & Group & Group & Group \\
\hline & 1 & 2 & 1 & 2 & 1 & 2 & 1 & 2 & 1 & 2 \\
\hline Epicardium & $1.74 \pm 0.34$ & $1.29 \pm 0.17$ & $0.53 \pm 0.21$ & $1.00+0.29$ & 0.005 & NS & $2.69 \pm 0.47$ & $1.98 \pm 0.31$ & 0.05 & 0.005 \\
\hline Endocardium & $1.52 \pm 0.25$ & $1.34 \pm 0.14$ & $0.56 \pm 0.30$ & $0.75 \pm 0.21$ & 0.01 & 0.05 & $1.95 \pm 0.30$ & $1.74 \pm 0.25$ & NS & 0.025 \\
\hline
\end{tabular}

by Anzai and associates, surface cooling was used to lower rectal temperature at $21^{\circ} \mathrm{C}$ in dogs [1]. Rewarming was also achieved by surface techniques without cardiopulmonary bypass. Minute ventilation was not altered from euthermic values $(\mathrm{pH}=7.32 \pm 0.15$ at $37^{\circ} \mathrm{C}$ ). Marked reductions in flow to the brain, heart and kidney were found during hypothermia with restoration of baseline flows upon rewarming, despite a cardiac output that remained significantly below baseline. The pattern of $\mathrm{pH}$ stat regulation was not examined.

Kawashima and colleagues studied the changes in the distribution of cardiac output by surface induced deep hypothermia in dogs using $\mathrm{pH}$ stat regulation [7]. Phenoxybenzamine was administered prior to hypothermia to minimize vasoconstriction. They found a uniform decrease in organ flow during hypothermia which closely paralleled the fall in cardiac output. Flows were not determined after rewarming.

Using perfusion cooling and rewarming, Rudy and associates noted a marked reduction in brain flow which did not return to baseline after rewarming [15]. Myocardial blood flow was unaffected, while renal flow decreased during cooling and then returned toward baseline. The arterial $\mathrm{pH}$ corrected to $15^{\circ} \mathrm{C}$ was $7.26 \pm 0.06$, a value far more acidotic than either of our two groups.

In another study, the effects of hypocarbia and normocarbia on cardiovascular dynamics and regional circulation were determined in surface cooled hypothermic dogs [12]. Adding
$\mathrm{CO}_{2}$ to the inspired gases to maintain a "normal" $p \mathrm{CO}_{2}$ during hypothermia ( $\mathrm{pH}$ stat regulation) was beneficial in maintaining cerebral perfusion but resulted in a significantly lower cardiac index.

This study compares two commonly used methods of $\mathrm{pH}$ regulation on the regional blood flows to the brain, kidney, and heart. Although it would have been preferable to control $\mathrm{pH}$ and $p \mathrm{CO}_{2}$ independently of each other, this would have difficult experimental implications. We chose to control $\mathrm{pH}$ by varying $p \mathrm{CO}_{2}$ as would be done clinically. This also allows for rapid and precise alterations during cooling and rewarming. Marked reductions in regional flows during hypothermia despite the maintenance of overall blood flow on bypass were found. This was not affected by the method of $\mathrm{pH}$ regulation, however. After rewarming, brain flow was restored to baseline levels, renal flow remained reduced, and myocardial flow was markedly increased over baseline. As with hypothermia, these trends remained consistent independent of the method of $\mathrm{pH}$ regulation.

Becker and colleagues noted improved maintenance of cerebral blood flow when a markedly alkalotic $\mathrm{pH}$ scheme was achieved by lowering the $p \mathrm{CO}_{2}$ [2]. Cooling was achieved predominantly by surface tecniques. The authors speculated that the improved cerebral perfusion was due to the maintenance of a higher systemic blood pressure and cardiac index in their alkalotic group. Although the $\mathrm{pH}$ schemes followed by Becker were not strictly comparable to those in this study (their 
groups were more alkalotic), the major difference appears to be our use of high flow cardiopulmonary bypass to achieve profound hypothermia, rather than allowing each organ to cool in proportion to its cardiac output as occurs with surface techniques. Since cardiac output is linear and fixed at normal levels on bypass, autoregulation in various organs may become less influential, and the effect of $\mathrm{pH}$ and $p \mathrm{CO}_{2}$ on that vasoregulation may be mitigated [2].

The increase in base excess during hypothermic perfusion noted in the $\mathrm{pH}$ stat animals may possibly indicate inadequate tissue perfusion compared to those in the alpha stat group. The base excess did not vary from control values among alpha stat animals and, in fact, improved slightly. This discrepancy between groups persisted after the rewarming. Although we did not measure lactate production, the results of Becker's study indicated that it was lactate accumulation which explained the greater base excess in their $\mathrm{pH}$ stat group [2]. However, an equally likely explanation for this finding relates to increased lactate production associated with alkalosis and hypothermia themselves. Therefore, we cannot conclude from our data that increased base excess necessarily implies inadequate tissue perfusion. Deep hypothermia for the correction of complex congenital defects is now often achieved entirely on cardiopulmonary bypass [22]. This study suggests that alterations in $\mathrm{pH}$ and $p \mathrm{CO}_{2}$ control between alpha and $\mathrm{pH}$ stat rcgulation assume lesser importance for regional blood flow when normal systemic flow is maintained during cooling and rewarming.

\section{ACKNOWLEDGMENT}

The authors express their gratitude to Carl E. Bredenberg, M.D. for his advice in the preparation of this manuscript.

\section{REFERENCES}

1. Anzai, T., Turner, M. D., Gibson, W. H., and Neely, W. A. Blood flow distribution in dogs during hypothermia and posthypothermia. Amer. J. Physiol. 234: $706,1978$.
2. Becker, H., Venten-Johansen, J., Buckberg, G. D., Robertson, J. M., Leaf, J. D., Lazar, H. L., and Manganaro, A. J. Myocardial damage caused by keeping pH 7.40 during systemic deep hypothermia. J. Thorac. Cardiovasc. Surg. 82: 810, 1981.

3. Berntman, L., Dahlgren, N., and Siesjo, B. K. Cerebral blood flow and oxygen consumption in the rat brain during extreme hypercarbia. Anesthesiology 50: 299, 1979.

4. Delin, N. A., Klartansson, K. B., Pollick, L., and Schenk, W. A., Jr. Redistribution of regional blood flow in hypothermia. J. Thorac. Cardiovasc. Surg. 49: $511,1965$.

5. Fox, L. S., Blackstone, E. H., Kirklin, J. W., Bishop, S. P., Bergdahl, L. A. L., and Bradley, E. L. Relationship of brain flow and oxygen consumption to perfusion flow rate during profoundly hypothermic cardiopulmonary bypass. I. Thorac. Cardiovasc. Surg. 87: 658, 1984.

6. Heymann, M. A., Payne, B. D., Hoffman, J. I. E., and Rudolf, A. M. Blood flow measurements with radionuclide-labeled particles. Prog. Cardiovasc. Dis. 20: 55, 1977.

7. Kawashima, Y., Okada, K., Kosugi, I., In-Nami, H., Yamaguchi, Y., Fugihara, T., and Yamamura, $H$. Changes in distribution of cardiac output by surfaceinduced deep hypothermia in dogs. J. Appl. Physiol. 40: 876, 1976.

8. Kunkel, R., Hagl, S., Richter, J. A., Habermeyer, P., and Scbening, F. The effects of decp hypothermia and circulatory arrest on systemic metabolic state of infants undergoing corrective open heart surgery: A comparison of two methods. Thorac. Cardiovasc. Surg. 27: 168, 1979.

9. Mavroudis, C., Brown, G. L., Katzmark, S. L., Howe, W. R., and Gray, L. A., Jr. Blood flow distribution in infant pigs subjected to surface cooling, deep hypothermia, and circulatory arrest. J. Thorac. Cardiovasc. Surg. 87: 665, 1984.

10. McConnell, D. H., White, F., Nelson, R. L., Goldstein, S. M., Maloney, J. V., Jr., Deland, E. C., and Buckberg, G. D. Importance of alkalosis in maintenance of "ideal" blood pH during hypothermia. Surg. Forum 26: 263, 1975.

11. Norwood, W. I., Norwood, C. R., Castaneda, A. R. Cerebral anoxia: Effect of deep hypothermia and $\mathrm{pH}$. Surgery 86: 203, 1979.

12. Ohmura, A., Wong, K. C., Westenskow, R., and Shaw, C. L. Effects of hypocarbia and normocarbia on cardiovascular dynamics and regional circulation in the hypothermic dog. Anesthesiology 50: 293, 1979.

13. Rahn, H., and Reeves, R. B. Hydrogen ion regulation during hypothermia: from the Amazon to the operating room. In (Prakash, O., Ed.), Applied Physiology in Clinical Respiratory Care. The Hague: Martinus Nijhoff. 1982. Pp. 1.

14. Ream, A. K., Reitz, B. A., and Silverberg G. Temperature correction of $\mathrm{pCO}_{2}$ and $\mathrm{pH}$ in estimating acidbase status. Anesthesiology 56: 41, 1982. 
15. Rudy, L. W., Boucher, J. K., and Edmunds, L. H., Jr. The effect of deep hypothermia and circulatory arrest on the distribution of systemic blood flow in rhesus monkeys. J. Thorac. Cardiovasc. Surg. 64: 706, 1972.

16. Swain, J. A. Regulation of $\mathrm{pH}$ during hypothermia (letter to the editor). J. Thorac. Cardiovasc. Surg. 85: $147,1983$.

17. Swain, J. A., White, F. N., and Peters, R. M. The effect of $\mathrm{pH}$ on the hypothermic ventricular fibrillation threshold. J. Thorac. Cardiovasc. Surg. 87: 445, 1984.

18. Turley, K., Roizen, M., and Ebert, P. A. Deep hypothermia and total circulatory arrest: The effect of method of cooling on the catecholamine response to arrest. J. Surg. Res. 30: 379, 1981.
19. Utley, J. R., Stephens, D. B., Wachtel, C., Cain, R. B., Collins, J. C., Spaw, E. A., Moores, W. Y. Effect of albumin and mannitol on organ blood flow, oxygen delivery, water content, and renal function during hypothermic hemodilution cardiopulmonary bypass. Ann. Thorac. Surg. 33: 250, 1982.

20. White, F. N. A comparative physiological approach to hypothermia. J. Thorac. Cardiovasc. Surg. 82: 821, 1981 .

21. Williams, J. J., and Marshall, B. E. A fresh look at an old question. Anesthesiology 56: 1, 1982.

22. Zarins, C. K., and Skinner, D. B. Circulation in profound hypothermia. J. Surg. Res. 14: 97, 1973. 